\title{
A COMPARATIVE STUDY OF TREATMENT OF CHRONIC BACKACHE BETWEEN CONVENTIONAL METHOD AND TRIGGER POINT INJECTIONS (TPI)
}

\author{
Hossain MHMD ${ }^{1}$, Choudhury MRA², Mojumder MMA3 .
}

\begin{abstract}
Non-specific low backache of mechanical origin is common symptoms of disability in the community. There are many causes of low backache; these are mechanical and non-mechanical types. The commonest form of low backache is structural dysfunction that has direct relationship with activity. There are many regimens of treatment of low backache and trigger points injection (TPI) is one modality of them. This comparative study between TPI and conventional treatment of chronic backache was carried out at Combined Military Hospital (CMH) Bogra over a period of one year where 60 patients were treated. Out of 60 patients, 30 patients in group-I was given conventional treatment and other 30 patients in group-II were provided TPI.

The mean age distribution was $42.33 \pm 5.79$ years in group-I and $43.76 \pm 6.35$ years in group-II, mean weight of the patients was $73.43 \pm 7.2 \mathrm{~kg}$ in group-I and $74.46 \pm 8.04 \mathrm{~kg}$ in group-II. Mean height of the patients were $165.33 \pm 9.84 \mathrm{~cm}$ in group-I and $166.50 \pm 9.10 \mathrm{~cm}$ in group-II. Mean duration of backache was $33.86 \pm 16.89$ months in group-I and 32.10. $\pm \mathbf{1 4 . 5 3}$ months in groupII and male female ratio was 18:12 in group-I and 22: 8 in group-II. In group-II TPI was provided, where their mean sessions of TPI requirement was 4.1 \pm 1.21 . After treatment, their mean visual analogue scale (VAS) was $4.77 \pm 0.76$ in group-I and $3.81 \pm 0.84$ in group-II which is not statistically significant and duration of mean pain relief was $3.78 \pm 0.79$ months in group-I and 5.65 \pm 1.21 months in group-II which is statistically significant. TPI is not a new modality of treatment of pain but it is not commonly practice in this country; which can be adopted for pain management usually without side effect.
\end{abstract}

Key Words: Backache, Trigger point injection (TPI).

\footnotetext{
Introduction

Complain of low backache is an extremely common medical entity and is second to the common cold as cause of work absences in patients less than 55 year of age and commonest cause of disability in population younger than 45 year $^{1}$.
}

The common form of low backache is mechanical type and $80-90 \%$ patients will complain of dull, achy, diffuse pain and stiffness that is confined to the low back area or may radiate to buttock and hip which results from reflex muscle spasm from primary pain, where there may have trigger points within their muscles ${ }^{2,3}$. Trigger points are discrete, focal, hyperirritable spots located in a taut band of skeletal muscle. They produce local and refer pain and often accompany chronic musculoskeletal disorders ${ }^{4}$.

There are many regimens of treatment of low backache, but most of the doctors practiced conventional method with bed rest, analgesics like non-steroidal antiinflammatory drugs (NSAIDs), muscle relaxants and sedative. Oral narcotics are also used for moderate to severe pain when it is unresponsive to NSAIDs. Among the many modalities of treatment of chronic pain, trigger points injection (TPI) is one modality. TPI is instillation of drug at trigger point that is rarely used by general practitioners and infrequently used by pain practitioner without ascertaining the actual cause and site, as a result its effectiveness is not properly evaluated.

In the present setup of pain management, especially for backache, radiological evidence and neurological examination get more importance than muscle examination of affected area, even though there is no correlation between the degenerative changes in the spine and the number and distribution of trigger points ${ }^{2}$. But proper muscle examination may give important clue of many pain of low back region, especially for myofascial pain which can be alleviated by very simple technique like deactivation of trigger points by saline, local anaesthetic or combination of local anaesthetic and steroid ${ }^{5-9}$.

In Bangladesh there is no study regarding TPI, so one comparative study between conventional treatment of backache and TPI was carried out at CMH Bogra from March 2005 to February 2006. In this study those patients were included who sustained trauma in their back or surrounding region, who work with overload, heavy weight or repetitive strenuous movement. In armed forces there is every chance of sustained trauma related to work with overload, heavy weight and repetitive movement as a part of their professional job. In this study, a mixture of local anaesthetic of injection of bupivacaine and steroid of injection methylprednisolone was used.

s1. Col MHM Delwar Hossain, MBBS, MCPS, DA, FCPS, Classified Specialist in Anaesthesiology, CMH, Dhaka 2. Brig Gen Md. Rezaul Alam Choudhury, MBBS, MD, Adviser Specialist in Anaestheiology, CMH, Dhaka 3. Maj Md. Masudur Alam Mojumder, MBBS, Graded Specialist in Anaesthesiology, CMH Bogra. 


\section{Material and Methods}

This prospective study was carried out on 60 patients of mechanical type of backache over a period of one year at CMH Bogra. Out of 60 patients, 30 patients in group-I was given conventional treatment and other 30 in groupII were given TPI. In both the groups adjuvant therapies were provided whenever it was required. All the patients were referred by doctors of different speciality from outpatient department and surgeons of $\mathrm{CMH}$ Bogra as nonresponsive to conventional treatment. After receiving the patients, history was taken and required physical examination and relevant investigations were done. therapies. Penetration of trigger points was accomplished with a 27 gauze $2 \mathrm{~cm}$ needle for superficial muscles and 25 gauge $5 \mathrm{~cm}$ needle for deep muscle. The needle is directed at the most sensitive part of the trigger points, and advanced until the trigger point is penetrated. Penetration of the trigger point could be elicited by exquisite tenderness, observations of local twitch response ('jump sign') and patient felt pain not only locally but also at the zone of reference. Once trigger point is penetrated, a total of 1 to $2 \mathrm{ml}$ of solution of injection of $0.25 \%$ plain bupivacaine with $10 \mathrm{mg}$ methylprednisolone acetate was injected under some

Table - I: Procedure for trigger points search and response.

\begin{tabular}{|c|c|c|c|c|}
\hline $\begin{array}{c}\text { Types of muscle \& type of } \\
\text { causes }\end{array}$ & Procedures & Response & Area of reference & Muscles involved \\
\hline Each muscle under suspicion & $\begin{array}{l}\text { Muscle should be placed slightly } \\
\text { on the stretch \& apply firm } \\
\text { pressure }\end{array}$ & $\begin{array}{l}\text { Local twitch } \\
\text { response or } \\
\text { "Jump sign" }\end{array}$ & $\begin{array}{l}\text { When backache is refered to } \\
\text { midline }\end{array}$ & Multifidus \& Rotators \\
\hline When a muscle overlies bone & $\begin{array}{l}\text { Draw the fingers firmly across } \\
\text { muscle similar to kneading } \\
\text { dough }\end{array}$ & "Jump sign" & $\begin{array}{l}\text { When backache refer to } \\
\text { buttock }\end{array}$ & $\begin{array}{l}\text { Gluteal muscles } \\
\text { Iliocostalis Lumborum, } \\
\text { Piriformis muscles }\end{array}$ \\
\hline $\begin{array}{l}\text { When muscle is relatively } \\
\text { free }\end{array}$ & Firmly hold the belly of muscle & "Jump sign" & $\begin{array}{l}\text { When backache referred down } \\
\text { the course of sciatic nerve }\end{array}$ & Erector spinae muscle. \\
\hline $\begin{array}{l}\text { When backache due to } \\
\text { twisting, stooping, bending, } \\
\text { walking, coughing or } \\
\text { sneezing }\end{array}$ & $\begin{array}{l}\text { Draw the fingers firmly across } \\
\text { muscle similar to kneading } \\
\text { dough. }\end{array}$ & "Jump sign" & $\begin{array}{l}\text { Low back region, buttock or } \\
\text { back of thigh }\end{array}$ & $\begin{array}{l}\text { Quadratus lumborum or } \\
\text { Iliopsoas muscle. }\end{array}$ \\
\hline $\begin{array}{l}\text { When pain over the sciatic } \\
\text { notch during abduction or } \\
\text { externally rotated against the } \\
\text { resistance }\end{array}$ & $\begin{array}{l}\text { Apply firm pressure and draw } \\
\text { the fingers firmly across muscle } \\
\text { similar to kneading dough. }\end{array}$ & "Jump sign" & Low back region $\&$ buttock & Piriformis muscles \\
\hline
\end{tabular}

Physical examination had been carried out with the patient standing and with sufficient clothes removed to give an uninterrupted view of the whole length of spine and legs. Final part of examination had been carried out very carefully to search for trigger points. This search had conducted in systematic and unhurried manner. Trigger point in the lower back occurred as focal area of exquisite tenderness either in belly of muscle or in connective tissue, which could be felt on palpation during examination as hypersensitive bundle or nodule of muscle fiber of harder than normal consistency. Localization of a trigger point is based on the physician's sense of feel, assisted by patient expressions of pain during examination or by visual and palpable observations of local twitch response ('jump sign') ${ }^{10}$. Search for trigger points was done as per Table -I.

Every alternate patient was given TPI and others were given conventional treatment. Visual analogue scale (VAS) was familiarized by all the patients and initial VAS were measured. All the data of each patient were recorded in data collection sheet for the purpose of study.

In group-I, conventional treatment was given by NSAIDs, bed rest with adjuvant therapies like muscle relaxants and physiotherapy and in group-II treatment was directed toward the trigger points by TPI along with adjuvant pressure. This might cause further exaggeration of the local or referred pain and tenderness.

In every case, two sessions of TPI was given per week. Patients not responded to 2 sessions of TPI, were provided with adjuvant therapies with muscle relaxant and physiotherapy. Muscle relaxant like diazepam, tolperisone or epirisone was used and physiotherapy likes pelvic traction or heat was provided. Those patients who were anxious, depressed due to long duration of backache or psychologically affected were provided with tricyclicanti depressant drugs like amitryptyline, imipramine or combination of fluphenazine and nortriptyline. Adjuvant therapy for this study, when only one regimen was used then count as 1, when two regimens were used then count as 2 and when all three were used then count as 3 for the convenience of study. Visual analogue scale (VAS) of patients was evaluated just few minutes after TPI and next visit which was recorded in data sheet and after 07 days; their VAS was summated and average VAS score was recorded.

\section{Results}

This study was carried out on 60 patients of backache; their demography is depicted in Table-II and Figure-1. At the time of history taking it was found that among 60 
patients, 30 patients (13 in group-I and 17 in group-II) had sustained trauma during their training and daily activities, 18 patients (10 in group-I and 8 in group-II) gave history of work with heavy weight or overload and 12 patients (7 in group-I and 5 in group-II) found unhappy with their working environment and their family life which is shown in Table-III.

Table-II: Demography of study gruop patients.

\begin{tabular}{|c|c|c|}
\hline Variable & Group-I & Group-II \\
\hline Mean Age in years & $42.33 \pm 5.79$ & $43.76 \pm 6.35$ \\
\hline Sex & $18: 12$ & $22: 8$ \\
\hline Mean Weight (kg) & $73.43 \pm 7.27$ & $74.46 \pm 8.04$ \\
\hline Mean Height (cm) & $165.33 \pm 9.84$ & $166.50 \pm 9.10$ \\
\hline $\begin{array}{c}\text { Mean Duration of } \\
\text { backache (months) }\end{array}$ & $33.86 \pm 16.89$ & $32.10 . \pm 19.53$ \\
\hline
\end{tabular}

Among the 60 patients in both groups, 15 patients (6 in group-I and 9 in group-II) were anxious and depressed for their chronic backache. It was found that out of 60 patients, only 19 patients ( 7 in group-I and 12 in group-II) had mild to moderate radiological evidence and 23 patients ( 9 in group-I and 14 in group-II) had raised ESR. In group-I, no TPI was provided but in group-II it was

Table-III: Causes of backache of study group patients.

\begin{tabular}{|c|c|c|c|}
\hline Causes & $\begin{array}{c}\text { Group-I } \\
(\mathbf{n}=\mathbf{3 0}\end{array}$ & $\begin{array}{c}\text { Group-II } \\
(\mathbf{n}=\mathbf{3 0}\end{array}$ & $\begin{array}{c}\text { Total } \\
(\mathbf{n}=\mathbf{6 0}\end{array}$ \\
\hline Trauma & 13 & 17 & 30 \\
\hline Heavy weight & 10 & 08 & 18 \\
\hline Psychological & 07 & 05 & 12 \\
\hline
\end{tabular}

Table-IV: Effect of treatment in both study groups.

\begin{tabular}{|c|c|c|}
\hline Variable & $\begin{array}{c}\text { Group-I } \\
(\mathbf{n})=\mathbf{3 0}\end{array}$ & $\begin{array}{c}\text { Group-II } \\
(\mathbf{n})=\mathbf{3 0}\end{array}$ \\
\hline $\begin{array}{c}\text { TPI sessions } \\
\text { (Mean } \pm \text { SD) }\end{array}$ & $0 \pm 0$ & $4.1 \pm 1.21$ \\
\hline $\begin{array}{c}\text { Adjuvant (number) } \\
\text { (Mean } \pm \text { SD) }\end{array}$ & $0.8 \pm 0.99$ & $0.7 \pm 0.95$ \\
\hline $\begin{array}{c}\text { VAS (value) } \\
\text { (Mean } \pm \text { SD) }\end{array}$ & $4.77 \pm 0.76$ & $3.81 \pm 0.84$ \\
\hline $\begin{array}{c}\text { Duration of pain relief } \\
\text { (months) } \\
\text { (Mean } \pm \text { SD) }\end{array}$ & $3.78 \pm 0.79$ & $5.65 \pm 1.21$ \\
\hline
\end{tabular}

provided and mean sessions of TPI requirement was $4.1 \pm 1.21$. Their mean adjuvant requirement was $0.8 \pm 0.99$ in group-I and $0.70 \pm 0.95$ in group-II. Their mean VAS was $4.77 \pm 0.76$ in group-I and $3.81 \pm 0.84$ in group-II and mean duration of pain relief was $3.78 \pm 0.79$ months in group-I and 5.65 \pm 1.21 months in group-II; where $\mathrm{p}$ value was $<0.05$, which is shown in Table-IV. Out of 60 patients, 27 psychologically affected patients (12 unhappy and 15 anxious patients) were treated in this study; where 13 were in group-I and 14 were in group-II. All these patients were provided with tricyclic-anti depressant
Table-V: Effect of treatment of psychologically affected patients in study groups.

\begin{tabular}{|c|c|c|}
\hline Variable & $\begin{array}{c}\text { Group-I } \\
(\mathbf{n})=\mathbf{1 3}\end{array}$ & $\begin{array}{c}\text { Group-II } \\
(\mathbf{n})=\mathbf{1 4}\end{array}$ \\
\hline $\begin{array}{c}\text { TPI sessions } \\
\text { (Mean } \pm \text { SD) }\end{array}$ & $0 \pm 0$ & $3.92 \pm 1.73$ \\
\hline $\begin{array}{c}\text { Adjuvant (number) } \\
\text { (Mean } \pm \text { SD) }\end{array}$ & $1.93 \pm 0.75$ & $1.64 \pm 0.74$ \\
\hline $\begin{array}{c}\text { VAS (value) } \\
\text { (Mean } \pm \text { SD) }\end{array}$ & $4.80 \pm 0.85$ & $4.78 \pm 1.32$ \\
\hline $\begin{array}{c}\text { Duration of pain relief } \\
\text { (months) (Mean } \pm \text { SD) }\end{array}$ & $4.03 \pm 0.77$ & $4.78 \pm 1.84$ \\
\hline
\end{tabular}

drugs as an adjuvant therapy. The mean TPI requirement of psychological affected patients in group-II was 3.92 \pm 1.73 and mean VAS was $4.80 \pm 0.85$ in group-I and $4.78 \pm 1.32$ in group-II and mean pain relief was $4.03 \pm 0.77$ months in group-I and $4.78 \pm 1.84$ months in group-II, which is shown in Table-V.

\section{Discussion}

Trigger point is a small, circumscribed, hypersensitive region in muscles or connective tissue after acute injury or on long-standing chronic and recurrent muscle pain, which is occasionally palpable as nodule and harder than normal consistency ${ }^{2,10}$. The structure in which trigger points may be found are the skeletal muscle, their tendon, the capsule or ligaments of joints, the periosteum and the $\mathrm{skin}^{2,11-13}$. Irritation of the nociceptive receptor in the lumbar muscles, their fascial sheaths, tendinous insertions, the spinous ligaments and degenerative changes in the spine is a common cause of chronic low backache, because the structure in the vicinity of the spine has nociceptive reception ${ }^{14,15}$. Some physical factors which are capable of activating myofascial trigger points in the lumbar region are due to sudden or sustained overload of lumbar muscles, lifting of heavy weight or an object in awkward, stooping, standing or sitting position or in those people who are forces to work in prolonged sitting position or who are constantly moved about or may occur slowly where the micro-trauma occurs due to daily activities or repetitive movements ${ }^{16,17}$. Because trauma to muscle may cause an inflammatory reaction and cellular damage which are associated with the liberation of various chemical substances, these are capable of sensitizing A-delta and C sensory fibers ${ }^{18,19}$. In this study where TPI were provided in group-II, their mean VAS was $3.81 \pm 0.84$; which is less than group-I (4.77 \pm 0.76$)$ though it was not statistically significant but mean duration of pain relief was $5.65 \pm 1.21$ months which is prolonged than group-I ( $3.78 \pm 0.79$ months) which is statistically significant. It was also found in 1976 in a prospective study of 60 patients with chronic sciatica that by deactivating the trigger points by inserting dry needle, $71 \%$ pain was initially relieved and $53 \%$ pain was reliefed 
for 6 months duration ${ }^{20}$. The second group of this study (group-II) where mean VAS was $3.81 \pm 0.84$ and duration of pain relief was $5.65 \pm 1.21$ months which can be compared with this study in relation to their intensity and duration of pain relief.

The psychologically affected people may have an overactive reaction system, which have tendency to hold certain groups of muscles persistently tense. The incidence of backache is high in those who are not happy with their job or surrounding situation, divorced or have problem with alcohol ${ }^{21}$. It was found in a study in 1984 that, psychologically affected people had activated trigger point in their back region ${ }^{22,23}$. In this study out of 60 patients, total 27 psychologically affected patients were treated, among them 14 were provided with TPI (groupII); their mean VAS was $4.78 \pm 1.32$ and duration of pain relief was $4.78 \pm 1.84$ months, which were moderate in relation to pain relief and medium in relation to duration . Alleviation of low back pain is done by TPI when such pain is mechanical disorder or due to same structural dysfunction. Before contemplating the use of such treatment it is necessary to exclude other cause of low back pain of non-mechanical nature including inflammatory, metabolic and neoplastic disorder of the spine those has no relationship with physical activity ${ }^{2}$.

Mixture of injection of steroid with local anaesthetic gave better result than local anaesthetic alone ${ }^{24}$. The pain relieving effect of a locally injected steroid is largely due to the local anti-inflammatory action and partly due to its central action. It has also powerful irritant effect on peripheral nerve ending and evokes its activity in pain modulating mechanism in the central nervous system which causes its analgesic effect ${ }^{25}$. Steroid has characteristic softening and stretching effects on the collagen, help to grow of new fibrocytes and a consequently reduce tissue tension ${ }^{26,27}$. In this study, steroid injection of methlprednisolone was used along with local anaesthetic injection of bupivacaine in group-II where intensity and duration of pain relief was better than group-I.

There is a certain amount of pain relief following the first TPI, but this is short-lived, last for few hours to 1-3 days; some times it alone is sufficient to give long lasting relief from chronic pain, this is however is exceptional and normally several treatment sessions are required ${ }^{2,10}$. Each time TPI is given, the period of pain relief should increase and after third session will last for several days to months ${ }^{2}$. In this study in group-II, the mean TPI sessions were $4.1 \pm 1.21$, which provided a reasonable intensity of pain relief with medium duration. Complications of TPI are very less; these are tenderness, muscle spasm and local infection which persist for several hours to days ${ }^{2}$. In this study 12 patients complained of persistent pain of needle prick for one to three days after TPI.

\section{References}

1. John C Rowlingson. Low back pain and pain of lower extremity. In: P Prithvi Raj, editor. Practical management of pain. 2nd ed. USA: Mosby Year Book; 1992. p. 296.

2. Baldry PE. Acupuncture, trigger points and musculoskeletal pain. 2nd ed. USA: Churchill Livingstone; 1993. p. 100, 251,368.

3. Mc. Culloch JA. Differential diagnosis of low back pain. In: Tollison CD editor. Hand book of chronic pain management. Baltomore: William and Wilkins; 1989. p. 296-297.

4. David J Alvarez, Pamela G, Rockwell. Trigger Points: Diagnosis and management - a peer-reviewed. Journal of the American Academy of Family Physicians 2002; 65: 653-60.

5. Raj PP. Common blocks for chronic pain therapy. American Society of Anesthesiologist. 1988; 10:1-3.

6. Cailliet R, Davis FA. Soft tissue pain and disability. 1st ed. Philadelphia. 1977. p. 3, 32, 99.

7. Steindler A, Luck JV. Defferential diagnosis of pain in the low back. Journal of the American Medical Association. 1938; 110:106-112

8. Yates DW. A comparison of the types of epidural injections commonly used in the treatment of low-back pain and sciatica. Rheumatology and Rehabilitation. 1978; 3:181-186.

9. Green L N. Dexamethasone in the treatment of symptoms due to herniated lumbar disc. Journal of neurology, neurosurgery and Psychiatry 1975; 38:1211-1217.

10. Simons DG, Travell JG, Simons LS. Travell \& Simons' myofascial pain and dysfunction: the trigger point manual. $2 \mathrm{~d}$ ed. Baltimore: Williams \& Wilkins; 1999. p. 94-173.

11. Mann F. The treatment of disease by acupuncture. 3rd ed. London: Heinemann Medical; 1977. p. 123-129.

12. Sinclair DC. The remote reference of pain aroused in the skin. Brain. 1949; 72: 364-372.

13. De Valera E, Raftery H. Lower abdominal and pelvic pain in women. In: Bonica JJ, Albe-Fessard D, editors. Advances in pain research and therapy. New York: Raven Press; 1976. p. 935-936.

14. Wyke B. The neurology of low back pain. In: Jayson, editor. The lumbar spine and back pain. 3rd ed. Edinburgh: Churchill Livingstone; 1987. p. 59-74.

15. Lewit $K$. The needle effect in the relief of myofascial pain. Pain. 1979; 6: 83-90.

16. Duraja GP. Hand book of pain management. 1st ed. India: Mosby Saunders; 2004. p. 98-152.

17. Mogara A. Investigation of the relation between low-back pain and occupation to age, sex, community, education and other factors. Industrial Medicine and Surgery 1970; 39: 465-471.

18. Mense S. Neuron outflow from skeletal muscle following chemical noxious stimulation. Journal of Physiology 1977; 267: 75-88.

19. Mense S. Sensitization of group IV muscle receptors to bradykinin by 5- hydroxytryptamine and prostaglandin E2. Brain Research 1981; 225: 95-105.

20. King JS, Lagger R. Sciatica viewed as a referred pain syndrome. Surgical Neurology 1976; 5: 46-50.

21. Westrin CG. Low back sick listing. A sociological and medical insurance investigation. Scandinavian Journal of Social Medicine Supplement 1973; 7: 23-27.

22. Nathan PW. The gate control theory of Pain. A Critical Review. Brain 1976; 99: 123-158.

23. Flor H, Turk DC. Etiological theories and treatment for chronic back Pain Part I somatic models and interventions. Pain. 1984; 19:105-121.

24. Bourne IHJ. Treatment of chronic back pain comparing corticosteroid - lignocaine injections with lignocaine alone. The Practitioner 1984; 228: 333-338.

25. Glyn JH. Rheumatic pains: some concepts and hypotheses. Proceedings of the Royal Society of Medicine 1971; 64: 354-360.

26. Ketchum LD, Robinson DW, Masters FW. The Degradation of mature collagen. A laboratory study. Plastic and Reconstructive Surgery. 1968; 40: 89-91.

27. Ketchum LD. Effects of triamcinolone on tendon healing and function. A laboratory study. Plastic and Reconstructive Surgery 1971; 47: 471-482. 